\title{
Performance of Spring Wheat (Triticum aestivumL.) Varieties under Water Regimes and Nitrogen Rates
}

\author{
Sakumona M, Lungu DM, and Munyinda K \\ Plant Science Department, School of Agricultural Sciences, \\ University of Zambia, P.O.B0X 32379, Lusaka - Zambia
}

Corresponding Author:

Mushekwa Sakumona, Plant Science Department, School of Agricultural Sciences, University of Zambia, P.O. Box 32379, Lusaka, Zambia E-mail:sakumonam@yahoo.co.uk

\section{ABSTRACT}

The high cost of supplying water and nitrogen reduces the planted hectarage and restricts spring wheat production among wheat growers in Zambia. A field experiment was carried to determine twelve common spring wheat varieties' performance when subjected to water regimes and nitrogen application rates at Nanga Irrigation Research Station in Mazabuka in 2011 winter season. The experiment was performed as a Split-split in a Randomised Complete Block Design with three replications. Water regimes $(100 \%, 75 \%$ and $50 \%$ crop water requirements (CWR)) were considered as the main factor, nitrogen rates $(80,160$ and 240 $\mathrm{Kg} \mathrm{N} \mathrm{ha}^{-1}$ ) as sub-factor and variety (Nduna, Shine, Sekuru, Sahai I, Loerie II, Pungwa, Choza, UNZA I, UNZA II, Mampolyo, Nseba and Coucal) as a sub-sub factor. Grain yield, spike length, aboveground biomass, plant height, thousand kernel weight, harvest index, spikelets per spike and number of grains per spike were measured.

Mampolyo, Nduna and Pungwa significantly ( $p$ $<0.05$ ) produced the same and highest grain yield of $6,473,6,494$ and $6,395 \mathrm{~kg} \mathrm{ha}^{-1}$, respectively at $100 \% \mathrm{CWR}$ and lowest nitrogen rate. At 50\% CWR and optimum nitrogen rate, Loerie II $(5,351 \mathrm{~kg}$ $\left.\mathrm{ha}^{-1}\right)$ and Sahai I $\left(6,086 \mathrm{~kg} \mathrm{ha}^{-1}\right)$ significantly $(\mathrm{p}<$ 0.05 ) produced the same and highest yields. At $75 \%$ CWR and $160 \mathrm{~kg} \mathrm{~N}^{-1}$, Mampolyo $(5,703 \mathrm{~kg}$ $\left.\mathrm{ha}^{-1}\right)$ and Sekuru $\left(5,325 \mathrm{~kg} \mathrm{ha}^{-1}\right)$ significantly $(\mathrm{p}<$ $0.05)$ produced the same and the highest yields and $75 \% \mathrm{CWR}$ and $80 \mathrm{~kg} \mathrm{~N} \mathrm{ha}^{-1}$,Nseba $(5,667 \mathrm{~kg}$ $\left.\mathrm{ha}^{-1}\right)$, Shine $\left(5,224 \mathrm{~kg} \mathrm{ha}^{-1}\right)$ and Choza $\left(5,559 \mathrm{~kg} \mathrm{ha}^{-}\right.$ $\left.{ }^{1}\right)$ significantly $(\mathrm{p}<0.05)$ produced the same and highest grain yields. The optimum and low level of either water on nitrogen or vice versa and $80 \mathrm{~kg} \mathrm{~N}$ $\mathrm{ha}^{-1}$ with $75 \% \mathrm{CWR}$ offers wide options for spring wheat variety choice for wheat production.
It was concluded that farmers could select some varieties with high grain yields based on the input combination suiting their capacity and increase planted hectarage and wheat production.

Keywords: Grain yield, Wheat, Water, Nitrogen, Variety

\section{INTRODUCTION}

The high demand for fast and convenient foods in Zambia has led to increased wheat products consumption in the urban and peri-urban areas. Consumption of wheat products increased by $58 \%$ to 210,000 metric tons in five years since $2005^{10,11}$. This is making the temperate crop becoming a staple food crop. Although the current production of $240,000 \mathrm{mt}$ is sufficient to meet national consumption requirements with a surplus of $88,000 \mathrm{mt}$ going into export, this increase in production is attributed to the increased area under wheat cultivation. However, the crop is only grown during the winter season and the provision and management of water, and fertiliser nitrogen pose a production constraint which has led the commercial wheat farmers classification as low, medium and high yield management levels with wheat yields ranging from 5 to $7.5 \mathrm{Mtha}^{-1}$. This is because Zambia's rain season tends to experience warm temperatures with mean values ranging from 27 to $38^{\circ} \mathrm{C}$, which also has the potential to pose a threat of heat stress ${ }^{29,30}$.

The supply of water and nitrogen are the most limiting factors in wheat crop production and limits yield in rain-fed or irrigated conditions and non-fertilised agriculture ${ }^{2,3,16,21,26}$. These inputs are applied to improve yield components and ultimately increase grain yield and improve crop quality. Any stress caused by limited supply through low water irrigation or less nitrogen fertiliser application 
drastically decrease yields. Wheat farmers use a blanket recommendation of $450-500 \mathrm{~mm}$ of irrigation water either weekly or less or more and $240-355 \mathrm{~kg} \mathrm{Nha}^{-1}$ nitrogen fertiliser applied either once or split depending on management level ${ }^{14}$. These blanket recommendations were established for high input responsive varieties and seemed to be expensive and improper management practice.

The choice of a variety with the genetic potential to respond and produce better yields under limited input supply and management, mostly water and nitrogen is a critical and good management production decision. The decision has a large influence on increased land under cultivation and grain yield in wheat production. There is a high demand by wheat growers for high yielding spring wheat varieties with the ability to use low water and nitrogen application rates to meet the increasing consumer demand locally and in neighbouring countries ${ }^{1}$. Whilst strides have been made in evaluating maise under low water and nitrogen to mitigate food shortages by identifying and developing cultivars with ability to produce good yields under limited water and nitrogen supply in Zambia ${ }^{28}$; limited research has been done on Zambian wheat varieties. Farmers are opting to invest in machinery that would provide optimum water and nitrogen requirement for higher yields. However, this agronomic management practise is coming when there is a growing concern to manage the greenhouse gas emissions, demand for ecofriendly use of natural resources, and minimise environmental population ${ }^{27}$. Information on grain yield and yield components under different water regimes and nitrogen rates for some rain-fed and irrigated varieties on the market are limited. Therefore, in this study, the effects of reducing CWR $(100 \%, 75 \%$ and 50\%) and nitrogen application rates $\left(240,160\right.$ and $\left.80 \mathrm{~kg} \mathrm{~N} \mathrm{ha}^{-1}\right)$ on grain yield and yield components for commercially grown wheat varieties were reported.

\section{MATERIALS AND METHODS}

\section{Study Area}

The experimental site was NangaNational Agricultural Irrigation Research Station(Latitude $15^{\circ} 46^{\prime} \mathrm{S}$ and Longitude $27^{0} 55^{\prime} \mathrm{E}$ ), in Mazabuka Southern Province of Zambia during 2011 growing season. The soils were sandy clay loam in texture with a $\mathrm{pH}$ of 6.68 , organic matter of $1.12 \%$, the total nitrogen content of $0.1 \%$ and bulky density of $1.58 \mathrm{~g} \mathrm{~cm}^{-3}$.

\section{Experimental Design}

Field study involved twelve wheat varieties commonly grown by farmers; Nduna, Sahai I, Sekuru, Shine, UNZA I, UNZA II, Coucal, Mampolyo, Nseba, Choza, Loerie II and Pungwe. Water was supplied through irrigation in the growing season basing on crop requirement as $100 \%(506 \mathrm{~mm}), 75 \%$ and $50 \%$ while nitrogen in the form of urea was applied at rates of $80 \mathrm{~kg}$ Nha${ }^{1}, 160 \mathrm{~kg} \mathrm{Nha}^{-1}$ and $240 \mathrm{~kg} \mathrm{Nha}^{-1}$. The $100 \%$ CWR and $240 \mathrm{~kg} \mathrm{~N}^{-1}$ blanket recommendation were used to control the study. There were 108 treatment combinations which comprised of three water regimes as factor $A$ (main plot), three nitrogen rates as factor B (sub-plot) and twelve varieties as factor $\mathrm{C}$ (sub-sub plot). The experiment was a split-split plot design arranged in a Randomised Complete Block Design with three replications.

\section{Cultural Practices}

Planting rows measuring $1.5 \mathrm{~m} \times 0.2 \mathrm{~m}$ were marked in water basins, and basal dressing was applied at $500 \mathrm{kgha}^{-1}$ wheat basal with Avail booster $(9.20 \mathrm{~N}$; $21 \mathrm{P}_{2} \mathrm{O}_{5} ; 16 \mathrm{~K}_{2} 0 ; 12 \mathrm{~S} ; 0.8 \mathrm{Mg} ; 0.2 \mathrm{Cu} ; 0.3 \mathrm{Fe} ; 0.5 \mathrm{Zn}$; $0.2 \mathrm{~B})$ thereafter covered with soil. Three rows were planted per variety in winter wheat season of 2011 at a seed rate of $100 \mathrm{kgha}^{-1}$. Weeding was done manually in the seventh week after planting and subsequent broadleaf weeds, which emerged thereafter, were pulled out to maintain healthy plants. Water was applied to each treatment using sprinkler attached to flow meter. To prevent water drift in the neighbouring water basin, a $2 \mathrm{~m}$ plastic sheet was raised to enclose each basin during irrigation. The different nitrogen rates using avail coated urea $(46 \% \mathrm{~N})$ were applied at the eighth week after crop emergence taking into account nitrogen content in basal dressing.

\section{Data Collection}

Data for plant height, harvest index, above-ground biomass, number of grains per spike, spike length and spikelets per spike at physiological maturity stage were obtained from twelve tagged plants in the middle of each treatment plot. Grain yield per hectare at harvest was calculated and reported at $12.5 \%$ moisture content, and thousand kernel weight counted from grain yield per treatment and then weighed. 


\section{Data Analysis and Interpretation}

The collected data on grain yield and yield components were analysed statistically using the GENSTAT 13th Edition ${ }^{19}$. Data were then subjected to analysis of variance (ANOVA) using the General linear model procedure. Means were separated using Fisher's LSD at $\mathrm{P}<0.05$.

\section{RESULTS}

The Analysis of Variance showed that there were significant differences among varieties for grain yield and yield components at $\mathrm{p}<0.05$. Water regimes had significant $(p<0.05)$ effect on most parameters measured except thousand kernel weight, spikelets per spike and spike length. The factor nitrogen rate also had significant $(p<0.05)$ effect on measured parameters except on plant height, spikelets per spike and spike length. All factor interactions showed significant $(p<0.05)$ differences in the parameters measured apart from water by nitrogen interaction on spikelets per spike, which was non-significant.

\section{Effect of variety on grain yield}

Grain yield of varieties in the study were significantly $(\mathrm{P}<0.05)$ influenced by water and nitrogen application and by all interactions. Grain yields averaged across nitrogen rates and water regimes were lowest at $3,877 \mathrm{kgha}^{-1}$ for Coucal and highest at 5,064kgha-1 for Mampolyo (Table 1). Water regimes and Nitrogen rates averaged across varieties also significantly affected grain yield. Higher grain yield of $5,392 \mathrm{kgha}^{-1}$ was recorded at $100 \%$ CWR, 56\% higher than 50\% CWR (Table 2a). The lowest nitrogen rate of $80 \mathrm{~kg} \mathrm{Nha}^{-1}$ recorded $4,087 \mathrm{kgha}^{-1}$ grain yield, which was $15 \%$ lower than the yield at $240 \mathrm{~kg} \mathrm{Nha}^{-1}$ (Table 2b).

The influence of water regimes and nitrogen rates on varieties was also significant $(\mathrm{P}<0.05)$ on grain yield. The $100 \% \mathrm{CWR}$ and $160 \mathrm{~kg} \mathrm{Nha}^{-}$ 1 treatment combination showed superiority (5, $678 \mathrm{kgha}^{-1}$ ) over rest of combinations (Table 3), though the yield was not significantly different to the one produced by the combination of water and nitrogen blanket recommendation. Combined low water and nitrogen applications resulted in lowest grain yield $\left(2,970 \mathrm{~kg} \mathrm{ha}^{-1}\right)$, which was similar to $50 \% \mathrm{CWR}$ and $160 \mathrm{~kg} \mathrm{~N}^{-1}\left(3,447 \mathrm{~kg} \mathrm{ha}^{-1}\right)$.

As water and nitrogen stress increased, all varieties tended to reduce grain yield (Table 4 -
5).In optimum water supply, Mampolyo $(6,466 \mathrm{~kg}$ $\left.\mathrm{ha}^{-1}\right)$, Nduna $\left(6,253 \mathrm{~kg} \mathrm{ha}^{-1}\right)$, Pungwa $\left(5,943 \mathrm{kgha}^{-}\right.$ $\left.{ }^{1}\right)$ and Sahai I $\left(5,873 \mathrm{~kg} \mathrm{ha}^{-1}\right)$ produced the highest grain yield though grain yield of Loerie II was not different from that of Pungwa and Sahai I (Table 4). Sekuru, on the other hand, recorded the lowest grain yield of $4,746 \mathrm{~kg} \mathrm{ha}^{-1}$. When $75 \%$ CWRwas applied, seven varieties produced similar grain yields statistically, ranging from 4,522 to $4,932 \mathrm{~kg}$ ha $^{-1}$ while UNZA I with $3,908 \mathrm{~kg} \mathrm{ha}^{-1}$ was lowest. However, the grain yield of Sahai I and Loerie II in $50 \%$ CWRwas found similar to grain yield of high performing varieties at $75 \% \mathrm{CWR}$. Reducing CWRto 50\%, Loerie II $\left(4,408 \mathrm{kgha}^{-1}\right)$ and Sahai $\mathrm{I}\left(4,511 \mathrm{kgha}^{-1}\right)$ statistically produced the same highest grain yield while Coucal $\left(2,784 \mathrm{~kg} \mathrm{ha}^{-1}\right.$ was lowest.

Results in Table 5 show that in control, Mampolyo $\left(5,838 \mathrm{~kg} \mathrm{ha}^{-1}\right)$ and Sahai I $(5,669 \mathrm{~kg}$ $\left.\mathrm{ha}^{-1}\right)$ produced statistically the same and highest yield while Choza with $4,049 \mathrm{~kg} \mathrm{ha}^{-1}$ the lowest. Reducing nitrogen application rate to $160 \mathrm{~kg}$, $\mathrm{ha}^{-1}$ revealed Loerie II $\left(5,276 \mathrm{~kg} \mathrm{ha}^{-1}\right)$ and Nduna $\left(5,072 \mathrm{~kg} \mathrm{ha}^{-1}\right)$ as highest while Coucal lowest with $3,656 \mathrm{~kg} \mathrm{ha}^{-1}$, though grain yield of Mampolyo $\left(4,895 \mathrm{~kg} \mathrm{ha}^{-1}\right)$ was similar to that of Nduna. In the lowest nitrogen supply, Nduna with $4,856 \mathrm{~kg}$ $\mathrm{ha}^{-1}$ recorded the highest grain yield, which was not different statistically to Nduna's grain yield in $160 \mathrm{~kg} \mathrm{ha}^{-1}$ while Coucal was lowest with $3,171 \mathrm{~kg}$ $\mathrm{ha}^{-1}$. The peculiar responses of Nduna and Choza to nitrogen availability seem to have influenced response in water by nitrogen interaction. Both varieties had the lowest grain yield in optimum nitrogen supply as different CWRwas applied. Choza had the highest grain yield at $80 \mathrm{~kg} \mathrm{ha}^{-1}$ while grain yield in optimum nitrogen application rate and $160 \mathrm{~kg} \mathrm{ha}^{-1}$ was the same. Similarly, Nduna showed highest grain yield in $160 \mathrm{~kg} \mathrm{ha}^{-1}$, which was not significantly different to grain yield at $80 \mathrm{~kg} \mathrm{ha}^{-1}$.

The interactions of water regime, nitrogen rate and varieties also had pronounced significant effects on grain yield. Generally, most varieties followed the norm of decreased grain yield, reducing water and nitrogen supply (Table 6). Maximum grain yield was recorded by Mampolyo, Nduna and Loerie II with 7,346, 6,811 and 6,805kgha1 , respectively at optimum water and nitrogen application level while Coucal recorded lowest grain yield $\left(2,181 \mathrm{kgha}^{-1}\right)$ at $50 \% \mathrm{CWR}$ and $80 \mathrm{~kg}$ 
ha $^{-1}$ nitrogen application rate. Nduna $\left(3,590 \mathrm{kgha}^{-}\right.$ $\left.{ }^{1}\right)$, Choza $\left(3,555 \mathrm{~kg} \mathrm{ha}^{-1}\right)$ and Loerie II $\left(3,591 \mathrm{kgha}^{-}\right.$ $\left.{ }^{1}\right)$ produced the same and highest grain yields at $50 \%$ CWR and lowest nitrogen application rate. Two varieties (Nduna and Choza) showed an odd response in the influence of the water regime by nitrogen application rate interaction. Nduna tended to increase grain yield with a reduction in nitrogen application in all water regimes. Although the grain yield of Nduna in $50 \%$ CWR remained the same for all nitrogen application rates, a critical look still showed a decline in increased supply of nitrogen. Grain yield reduced by $4 \%$ between the lowest nitrogen supply to $160 \mathrm{~kg} \mathrm{~N} \mathrm{ha}{ }^{-1}$, $14 \%$ between $160 \mathrm{~kg} \mathrm{~N} \mathrm{ha}^{-1}$ to optimum and an overall of $17 \%$ between low application rate and optimum. The high performance of Choza at $75 \%$ water supply and $80 \mathrm{~kg} \mathrm{~N}^{-1}$ huggest ability to give grain yields at low input supply.

Grain yields of $6,494 \mathrm{~kg} \mathrm{ha}^{-1}$ (Nduna) and $6,473 \mathrm{~kg} \mathrm{ha}^{-1}$ (Mampolyo) were similar and highest at optimum water supply and $80 \mathrm{~kg} \mathrm{~N} \mathrm{ha}^{-1}$, and identical to $6,086 \mathrm{~kg} \mathrm{ha}^{-1}$ (Sahai I) at $50 \% \mathrm{CWR}$ supply and optimum nitrogen supply. Grain yields ranging from 5,000 to $5,700 \mathrm{~kg} \mathrm{ha}^{-1}$ were found similar to each other statistically when $75 \%$ CWR was applied on $60 \mathrm{~kg} \mathrm{Nha}^{-1}$ (Mampolyo, Sekuru and Loerie II) and $80 \mathrm{~kg} \mathrm{~N} \mathrm{ha}^{-1}$ far from Pungwa, Shine, Choza and Nseba. Hence, applying 75\% CWR on $80 \mathrm{~kg} \mathrm{~N}^{-1}$ application rate on the four varieties would conserve costs. The high grain yields from these varieties at optimum water and nitrogen using low nitrogen application rate and $50 \%$ crop water requirement, respectively; and $75 \%$ CWR on $80 \mathrm{~kg} \mathrm{~N} \mathrm{ha}^{-1}$ application rate offer options to growers to choose a variety suitable to their capacity, increase area under cultivation and optimise production.

\section{Effects of water regime on a variety of yield com- ponents}

The variations in yield components of varieties (Table 1) were influenced by applied water stress in the study. Water stress up to $50 \%$ crop water requirement reduced plant height by $22.45 \%$, harvest index by $18.97 \%$, above-ground biomass by $21.51 \%$ and the number of grains per spike by $27.13 \%$ while thousand kernel weight, spike length and spikelets per spike were not statistically affected by different water regimes (Table 2a).
Only plant height declined in all varieties with a reduction in crop water requirement. Thousand kernel weight, number of spikelets per spike and spike length generally remained the same in both $100 \%$ and $50 \%$ crop water requirement. Four varieties (Choza, Coucal, Nseba, Shine and UNZA I) increased in thousand kernel weight with increased water stress. Results also showed that yield components above-ground biomass, harvest index, and many grains per spike would remain stable in all water regimes in some varieties and decline in others.

\section{Effects of nitrogen rates on a variety of yield components}

Most yield components(thousand kernel weight, above-ground biomass, the number of grains per spike and harvest index) decreased with a reduction in nitrogen application except spikelets per spike, plant height and spike length not statistically affected by nitrogen application rates (Table $2 b$ ).

Subjecting varieties to differentnitrogen application rates showed different yield components in the study (Table 5). Reduced nitrogen supply decreased thousand kernel weight in Mampolyo, Sahai I, Sekuru and UNZA II and did not reduce thousand kernel weight in remaining varieties. Only two varieties, Sahai I and UNZA II tended to reduce the number of spikelets per spike while the ten varieties were relatively stable and produced the same number of spikelets in all nitrogen rates. A number of grains per spike increased (Sahai I, Mampolyo and UNZA II), remained stable and the same in Choza, Pungwa and Shine and declined in half of the study varieties reduction in nitrogen application. The length of spikes in the study only increased in Shine( from 5.90 to $6.71 \mathrm{~cm}$ ), decreased Sahai I, Nduna and UNZA II while the remaining varieties tended to remain the same a reduction in nitrogen supply from optimum to the lowest application rate.

The trend of varieties concerning above-ground biomass were; two varieties (UNZA II and Shine) increased above ground biomass with a reduction in nitrogen supply, three varieties (Loerie II, Sahai I and Sekuru) reduced above ground biomass with a reduction in nitrogen application, and three remaining varieties tended to maintain their aboveground biomass in high and low nitrogen supply (Table 5). 
Different behaviour was also observed among the varieties concerning their plant height and harvest index. Plant height of varieties increased in Choza and Nseba, decreased in Loerie II, Nduna, Pungwa, Sahai I and UNZA I and remained the same in five varieties when nitrogen supply was reduced optimum to lowest application rate in the study. However, the harvest index was observed increased in three varieties (Mampolyo, Nseba and UNZA I) and remained the same in both high and low nitrogen supply in nine varieties.

\section{Effects of water regimes and nitrogen rates in- teraction on the variety yield components}

Averaged across all varieties, yield components were significantly affected by the interaction of water regime and nitrogen rates except the number of spikelets per spike (Table 3). Harvest index of $28.27 \%$ in optimum water and nitrogen supply interaction was the highest and lowest in $50 \%$ crop water requirement and $80 \mathrm{~kg} \mathrm{~N} \mathrm{ha}^{-1}$ with $17.99 \%$. Although plant height declined with water supply, all nitrogen rates in optimum and $75 \%$ crop water requirement maintained the same plant heights. Plant heights only declined in 50\% crop water requirement with reductions in nitrogen application rates from $68.67 \mathrm{~cm}$ (optimum) to $60.75 \mathrm{~cm}\left(80 \mathrm{~kg} \mathrm{~N} \mathrm{ha}^{-1}\right)$. A number of grains per spike remained stable and same in optimum and $75 \%$ crop water requirements when interacting with all nitrogen rates and was only different in $50 \%$ crop water requirement where it declined with reduced nitrogen supply.

The interactions of reducing CWR from 75 to $50 \%$ with nitrogen applications rates, showed a non-significant effect on spike length. The interactions of optimum CWR and optimum nitrogen and $160 \mathrm{~kg} \mathrm{~N} \mathrm{ha}{ }^{-1}$ produced longer spike length, but not significantly different from spike length of optimum water by $80 \mathrm{~kg} \mathrm{~N}^{-1}$ $(7.01 \mathrm{~cm})$, optimum nitrogen and 50\% CWR interaction $(6.72 \mathrm{~cm})$ and $75 \% \mathrm{CWR}$ and $80 \mathrm{~kg}$ $\mathrm{N}$ ha-1interaction $(6.62 \mathrm{~cm})$. The above-ground biomass remained the same in optimum CWR and $75 \%$ CWR for all nitrogen application rates and only reduced in $50 \%$ crop water requirement as nitrogen application reduced. The thousand kernel weight of optimum CWR and 75\% CWR when applied on $80 \mathrm{~kg} \mathrm{~N} \mathrm{ha}^{-1}$ lead to $44.01 \mathrm{~g}$ and 46.21 $\mathrm{g}$, respectively which were similar and lightest grains. Heavier thousand kernel weight of $50.89 \mathrm{~g}$ was observed in the $50 \% \mathrm{CWR}$ and $160 \mathrm{~kg} \mathrm{~N} \mathrm{ha}^{-1}$ application rate interaction, though not different from that recorded in optimum nitrogen in both 75 and 50\%CWR and optimum CWR and $160 \mathrm{~kg} \mathrm{~N}$ $\mathrm{ha}^{-1}$ application rate interaction.

The interactions of variety with water and nitrogen rates (Table 6) showed significant effects on all yield components. Generally, the responses of most varieties seem to have been controlled by the availability of nitrogen fertiliser and the variety's behaviour in absorbing nitrogen from the soil. All yield components were reduced with the decreased application of water and nitrogen.

\section{DISCUSSION}

Maximum grain yields observed from high yielding varieties in this study might be attributed to the improvements in their yield components (Table $1-6$ ). Most high yielding varieties either increased or maintained their yield components when CWR and nitrogen application rate was decreased. Obtained study results are similar to findings of numerous studies $5,6,9,22,26$ that showed the presence of wide genetic background and different variety responses of cultivated wheat varieties in different water and nitrogen levels with regards to their grain yield. These researchers ${ }^{5,6,9}$, 22,26 attributed their observed variations in variety grain yield to variations in their yield components. This may explain the behaviour exhibited by Choza and Nduna, which increased grain yield with decreased nitrogen application rate in both nitrogen as a factor and its interaction with water regime. Similarly, Nouri ${ }^{13,17}$ also observed that varieties responded differently at different water and nitrogen application levels while Maqsood $^{7}$, ${ }^{12}$ also found that grain yield of wheat increased with the increasing rate of nitrogen fertilisation and a number of irrigation. Reducing the blanket applications for the inputs led to reduced grain yields in the study, which is an indication that the input combination plays critical roles in the biochemical and physiological processes of plant growth and development.

Although several researchers had observed a decrease in yield components when irrigation schedules were varied ${ }^{6,21,25}$, results of this study did not follow the normal expectation of a reduction in most yield components with water stress in most varieties (Table 4). The 
results confirm the complexity in which plants respond to water stress, resulting from alterations in molecular, biochemical and physiological changes, ultimately influencing morphology and phenology of plants leading to varying levels of responses in yield components ${ }^{18}$. Pauk ${ }^{18}$ reported that molecular and physiological changes which influence morphology and phenology of plants tend to lead to varying levels of responses in yield components. Pauk ${ }^{18}$ further observed that water stress was one of the most important stress factors that cause complex plant responses.

Either variety yields or yield components, decreased, increased, or remained the same with a reduction in the study's nitrogen application rates (Table 5). Obtained results for decreased yield and yield components as nitrogen application reduced are consistent with findings reported by $\mathrm{Iqbal}^{7}$, 13, 20, 25, 26. The peculiar characteristic (increase in grain yield with decreased nitrogen application rate) showed by the varieties of Choza and Nduna is explained by the maintenance of their yield components with a reduction in nitrogen rates and suggest the potential for the increasing area under cultivation and reduced pollution from the detrimental effects of nitrogenous substances in the ecosystem. All yield components reduced with the decreased application of water and nitrogen inputs. Similar results have been reported by other researchers ${ }^{13,26}$. Reductions in yield components with reductions in water regimes and nitrogen application rates, suggests the critical role for both water and nitrogen in improving yield components in crops.

\section{CONCLUSION}

This study has shown that there are options to increase the wheat area under cultivation and encourage production. Optimum CWR and $80 \mathrm{~kg} \mathrm{~N}$ $\mathrm{ha}^{-1}$ application rate and optimum nitrogen supply and 50\% CWRproduced high and economic grain yields of above $6,000 \mathrm{~kg} \mathrm{ha}^{-1}$ which were similar for Sahai I, Nduna and Mampolyo varieties. The insignificant differences recorded among high grain yielding varieties under $50 \% \mathrm{CWR}$ and optimum nitrogen supply and $75 \% \mathrm{CWR}$ and $80 \mathrm{~kg} \mathrm{~N} \mathrm{ha}^{-1}$ application rate, would suggest that choosing a variety from the latter is a good management production decision to minimise costs and increase on wheat productivity. Results suggest a need for evaluation studies ofZambianwheat varieties on the market to provide information for production decisions that could conserve producer costs, mitigate ecosystem nitrogen pollution, and optimise production. The variations in variety grain yield and yield component responses also offer wheat breeders opportunities to make suitable varieties even for low input supply to encourage resource-poor farmers to participate in wheat cultivation.

\section{ACKNOWLEDGEMENTS}

This work is part of the MSc Dissertation and authors thank the National Irrigation Research Station (NIRS)for the trial site and logistical support, Dr Elijah Phiri of University of Zambia (UNZA) in the Soil Science Department for provision of an irrigation schedule, ZARI, SEEDCO, ZAMSEED and UNZA for the provision of varieties used in the study, Greenbelt Fertilisers Zambia for provision of fertilisers and Kashano Beatrice for funding the research.

\section{REFERENCES}

1. Agricultural Consultative Forum (ACF). 2011. Wheat value chain in Zambia. ACF Report of 2011. Lusaka. Zambia.

2. Ali, L., Q, May-Ud-Din and M. Ali. 2003. Effect of different doses of nitrogen fertiliser on yield of wheat. Int. J. Agric. Biol. 5(4): 438- 439.

3. Davies, W.J., J. Zhang., J. Yang and I.C. Dodd. 2011. Novel Crop Science to improve yield and resource use efficiency in water-limited agriculture: Foresight Project on Global food and farming futures. Journal of Agricultural Science. 149: 123 - 131.

4. Fallahi, H. A., A. Nasseri and A. Siadat. 2008. Wheat yield components are positively influenced by nitrogen application undermoisturedeficitenvironments. Int. J. Agri. Biol.10(6): $673-676$.

5. Gorny, A. G., Z. Banaszak., B. Lugowska and D. Ratajcka. 2011. Inheritance of the efficiency of nitrogen uptake and utilisation in winter wheat (Triticum aestivum L) under diverse nutritional levels. Euphytica. 177: 191 $-206$.

6. Guendouz, A., S. Guessoum., K. Maamari and M. Hafsa. 2012. Effects of supplementary irrigation on grain yield, yield components and some morphological traits of durum 
wheat (Triticum Durum Desf.) cultivars. Adv. Environ. Biol. 6(2): 564 - 572.

7. Igbal, J., S. Hussain., A. Ali and M. A. A. H. A. Bakhsh. 2012. Effect of Seeding Rates and Nitrogen Levels on Yield and Yield components of wheat (Triticum aestivum L). Pak. J. Nutr. 11 (7) : $531-536$.

8. Jamali, K. D and S. A. Ali. 2008. Yield and yield components with relation to plant height in semi-dwarf wheat. Pak. J. Bot., 40(4): 1805 $-1808$

9. Le Louis, J., D. Beghim., E. Heumez and E. Pluchard. 2000. Genetic differences for nitrogen uptake and nitrogen utilisation efficiencies in winter wheat. European Journal of Agronomy. 12: 163 - 173.

10. MACO. 2010. Crop forecast statistics. Ministry of Agriculture and Cooperatives (MACO). Lusaka. Zambia

11. MACO/CSO. 2011. National food balance for Zambia for the 2011/12 Agricultural Marketing Season. Ministry of Agriculture and Cooperatives (MACO) / Central Statistics Office (CSO). Lusaka. Zambia.

12. Maqsood, M., A. Ali., Z. Aslam., M. Saeed and S. Ahmad. 2002. Effect of irrigation and nitrogen levels on grain yield and quality of wheat (Triticum aestivum L). Int. J. Agri. Biol. 4(1): $164-165$.

13. Mirzadeh, H., Y. Emam., P. Pilesjo and $H$. Seyyedi. 2011. Water use efficiency of four dryland wheat cultivars under different levels of nitrogen fertilisation. J. Agri. Sci. Tech. 13: $843-854$.

14. Muoleki, P. 1997. Wheat and Barley (Triticum aestivum $L$ and Hordeum vulgare $L$. sensulato). In: Muliokela S.W (Ed). Zambia Seed Technology Hand Book. Ministry of Agriculture, Food and Fisheries. pp: $154-158$. Lusaka. Zambia.

15. Musaddique, T., A. Hussain., S. A. Wajid and A. Ahmad. 2000. Growth, yield and components of yield of different genotypes of wheat. Int. J. Agri.Biol.2 (3): $242-244$.

16. Mushtaq, T., S. Hussain., M. A. H. A. Bukhsh., J. Iqbal and T. Khaliq. 2011. Evaluation of two wheat genotypes performance of under drought conditions at different growth stages. Crop \& Environment. 2 (2): $20-27$.

17. Nouri, A., A. Etminam., J. A. Teixeira da Silva and R. Mohammadi. 2011. Assessment of yield, yield-related traits and drought tolerance of durum wheat genotypes (Triticum turjidumvar.durumDesf). AJCS 5(1): $8-16$.

18. Pauk, J. R., R. Mihaly., C. Lantos, C. Flamm., B. Teizer., E. Zechner., M. Livaja., M. Sdimoke., L. Cseuz and S. Ruthner. 2010. Wheat under environmental stress: Experiments with 25 elite genotypes within the CORNET network. Tagung der Vereinigung de Pflanzenzuchter und SaatgutkaufleuteOsterreichs. $135-139$.

19. Payne,R.W., S.A. Harding., D. A. Murray., D. M. Soutar., D. B. Baird., A.I. Glaser., S.J. Welham., A.R. Gilmour., R. Thompson and R. Webster. 2011. GenStat Release 14. VSN International Ltd.

20. Sangtarash, M. H. 2010. Responses of different wheat genotypes to drought stress applied at different growth stages. Pak. J. Biol. Sci. 13(3): 114 - 119.

21. Shamsi, K., M. Petrosyan., G. Noo-Mohammadi and R. Haghparast. 2010. The role of water deficit stress and water use efficiency on bread wheat cultivars. J. Appl. Biosci. 35: $2325-2331$.

22. Sial, M. A., M. U. Dahot., M. A. Arain., G. S. Marchand., S. M. Mangrio., M. H. Naqvi., K. A. Laghari and A. A. Mirbahar. 2009.Effect of water stress on yield and yield components of semi-dwarf bread wheat (Triticum aestivum. L). Pak. J. Bot. 41(4): 1715 1728.

23. Tas, $S$ and B. Tas. 2007. Some physiological responses of drought stress in wheat genotypes with different ploidity in Turkiye. World . J. Agric. Sci. 3 (2): $178-183$.

24. Yousufzai, M-N. K. 2007. Evaluation on anatomic and morphological traits in relation to low water requirement conditions of bread wheat (Triticum aestivum L). Pak. J. Bot. 39(7): $\quad 2725-2731$.

25. Waraich, E. A., R. Ahmad., A. Ali and S. Ullah. 2007. Irrigation and nitrogen effects on brain development and yield in wheat (Triticum aestivum. L). Pak. J. Bot. 39 (5): 1663 - 1672.

26. Woyema, A., G. Bultosa and A. Taa. 2012. Effect of different nitrogen fertiliser rates on yield and yield-related traits for seven Durum wheat (Triticum turgidium L. var Durum) cultivars grown at Sinan, South Eastern Ethiopia.AJFAND 12 (3):6079 - 6094.

27. CIMMYT and ICARDA. 2011. Wheat-Global Alliance for Improving Food Security and 
Livelihoods of the Resource-poor in the Developing World. Proposal submitted by CIMMYT and ICARDA to the CGIAR Consortium Board in collaboration with Biodiversity, ICRISAT, IFPRI, ILIRI and IWMI. MEXICO, CIMMYT.

28. Miti, F.2007. Breeding investigations of maise (Zea mays L.) genotypes for tolerance to low nitrogen and drought in Zambia. $\mathrm{PhD}$ Thesis. University of KwaZulu- Natal. Re- public of South Africa.

29. Machida, M.R. 1985. Agricultural climates of Zambia: Agrometeorological Report No. 9. Meteorological Department, Lusaka. Zambia.

30. Ndiyoi, M and Phiri, M. 2010. Livelihood zones of Zambia: Farmers' Typology and Location. Farming Systems Association of Zambia. Lusaka. Zambia. 
Table 1: Means of Genotypes on Grain Yield and Yield components

\begin{tabular}{|l|c|c|c|c|c|c|c|c|}
\hline Genotypes & Yield & TKW & SE & B.M. & E L & GE & HI & PHT \\
\hline Choza & 4,228 & 50.75 & 12.51 & 52.7 & 6.69 & 19.79 & 23.96 & 76.01 \\
\hline Coucal & 3,877 & 49.55 & 12.78 & 62.08 & 6.18 & 20.53 & 17.47 & 85.85 \\
\hline Loerie II & 4,828 & 49.50 & 12.26 & 59.97 & 6.73 & 21.18 & 27.82 & 74.38 \\
\hline Mampolyo & 5,064 & 48.50 & 13.26 & 67.98 & 6.92 & 26.01 & 28.51 & 74.95 \\
\hline Nduna & 4,694 & 44.35 & 11.94 & 45.51 & 6.35 & 19.40 & 24.92 & 68.82 \\
\hline NBA & 4,517 & 46.84 & 11.62 & 56.36 & 6.57 & 20.61 & 24.39 & 74.63 \\
\hline Pungwe & 4,768 & 43.56 & 12.18 & 49.45 & 6.68 & 18.36 & 24.41 & 74.60 \\
\hline Sahai I & 4,979 & 50.56 & 12.02 & 61.62 & 6.74 & 20.82 & 24.74 & 77.16 \\
\hline Secure & 4,253 & 50.16 & 13.12 & 60.89 & 7.37 & 16.77 & 22.05 & 72.97 \\
\hline Shine & 4,264 & 49.97 & 11.51 & 59.21 & 6.25 & 19.50 & 23.10 & 71.30 \\
\hline UNZA I & 4,047 & 45.68 & 10.20 & 41.45 & 6.28 & 15.63 & 23.08 & 69.57 \\
\hline UNZA II & 4,108 & 47.01 & 11.47 & 58.03 & 6.35 & 16.27 & 22.27 & 70.58 \\
\hline LSD @ 5\% & 192.1 & 1.48 & 0.50 & 3.02 & 0.22 & 1.42 & 1.31 & 1.49 \\
\hline CV (\%) & 8.00 & 5.70 & 7.70 & 10.10 & 6.30 & 13.60 & 10.20 & 3.70 \\
\hline
\end{tabular}

Table 2: Effect of Water Regimes and Nitrogen Rates on Grain Yield and Yield Components

\begin{tabular}{|c|c|c|c|c|c|c|c|c|}
\hline & Yield & TKW & BM & $\mathbf{E L}$ & GE & HI & PHT & $\mathbf{S E}$ \\
\hline \multicolumn{9}{|c|}{ (a) WATER REGIMES (W) } \\
\hline W $1(100 \%)$ & 5,392 & 46.72 & 59.61 & 7.14 & 21.6 & 25.99 & 83.3 & 13.08 \\
\hline W $2(75 \%)$ & 4,482 & 47.62 & 61.17 & 6.39 & 21.38 & 24.64 & 74.81 & 11.83 \\
\hline W $3(50 \%)$ & 3,533 & 49.77 & 46.79 & 6.24 & 15.74 & 21.06 & 64.60 & 11.30 \\
\hline LSD (5\%) & 614.5 & NS & 5.41 & NS & 3.44 & 1.99 & 4.25 & NS \\
\hline \multicolumn{9}{|c|}{ (b) NITROGEN RATE ( N) } \\
\hline N $1\left(240 \mathrm{~kg} \mathrm{Nha}^{-1}\right)$ & 4,832 & 48.69 & 58.09 & 6.77 & 20.93 & 24.76 & 74.53 & 12.32 \\
\hline N $2\left(160 \mathrm{~kg} \mathrm{Nha}^{-1}\right)$ & 4,488 & 49.23 & 54.36 & 6.527 & 19.13 & 24.37 & 74.27 & 12.11 \\
\hline N $3\left(80 \mathrm{~kg} \mathrm{Nha}^{-1}\right)$ & 4,087 & 46.19 & 55.12 & 6.482 & 18.66 & 22.55 & 73.9 & 11.79 \\
\hline LSD (5 \%) & 178.8 & 0.71 & 1.78 & NS & 1.02 & 0.83 & NS & NS \\
\hline
\end{tabular}

B.M.: Above ground biomass, G.E.: Grains per ear, PHT : Plant height, HI : Harvest index

S.E.: $\quad$ Spikes per ear, E.L.: Ear length 
Table 3 : Effect of Water regime and Nitrogen rate interaction on Grain Yield and Yield Components

\begin{tabular}{|c|c|c|c|c|c|c|c|c|c|}
\hline \multicolumn{2}{|l|}{ Interaction } & Yield & TKW & BM & EL & GE & HI & PHT & SE \\
\hline \multirow{3}{*}{ W 1 } & N 1 & 5,601 & 47.18 & 59.90 & 7.29 & 22.51 & 28.27 & 81.48 & 13.05 \\
\cline { 2 - 9 } & N 2 & 5,678 & 48.88 & 59.43 & 7.13 & 21.62 & 25.49 & 84.14 & 13.59 \\
\cline { 2 - 10 } & N 3 & 4,897 & 44.10 & 59.48 & 7.01 & 20.66 & 24.21 & 84.28 & 12.61 \\
\hline \multirow{2}{*}{ W 2 } & N 1 & 4,714 & 48.74 & 61.60 & 6.30 & 21.47 & 24.93 & 73.46 & 11.99 \\
\cline { 2 - 10 } & N 2 & 4,338 & 47.91 & 60.24 & 6.25 & 20.67 & 23.54 & 74.29 & 11.60 \\
\cline { 2 - 10 } & N 3 & 4,393 & 46.21 & 61.67 & 6.62 & 21.98 & 25.44 & 76.68 & 11.92 \\
\hline \multirow{2}{*}{ W 3 } & N 1 & 4,182 & 50.15 & 52.76 & 6.72 & 18.80 & 21.09 & 68.67 & 11.92 \\
\cline { 2 - 10 } & N 2 & 3,447 & 50.89 & 43.39 & 6.20 & 15.10 & 24.08 & 64.38 & 11.13 \\
\cline { 2 - 10 } & N 3 & 2,970 & 48.27 & 44.23 & 5.81 & 13.33 & 17.99 & 60.75 & 10.85 \\
\hline \multicolumn{2}{|l}{ LSD(5\%) } & $\mathbf{6 0 3 . 6}$ & $\mathbf{2 . 6 1}$ & $\mathbf{5 . 3 6}$ & $\mathbf{0 . 7 9}$ & $\mathbf{3 . 3 8}$ & $\mathbf{2 . 0 3}$ & $\mathbf{4 . 2 3}$ & NS \\
\hline
\end{tabular}

BM: Above ground biomass, GE : Grains per ear, PHT : Plant height, HI : Harvest index SE : Spikes per ear, E.L.: Ear length

W 1 : $\quad 100 \%$, W 2: $75 \%$, W 3: $\quad 50 \%$, N 1: $240 \mathrm{kgha}^{-1}, \mathrm{~N} 2: 160 \mathrm{kgha}^{-1}$, N 3: $80 \mathrm{kgha}^{-1}$ 
Table 4: Effect of Water Regimes and Genotype Interaction on Grain Yield and Yield Components

\begin{tabular}{|c|c|c|c|c|c|c|c|c|c|}
\hline Genotype & Water & Yield & TKW & BM & EL & GE & HI & PHT & $\mathrm{SE}$ \\
\hline \multirow[t]{3}{*}{ Choza } & W 1 & 4,815 & 50.19 & 65.63 & 7.10 & 22.51 & 24.14 & 84.60 & 13.47 \\
\hline & W 2 & 4,373 & 44.57 & 49.90 & 6.54 & 20.31 & 26.08 & 74.16 & 12.03 \\
\hline & W 3 & 3,495 & 57.48 & 42.58 & 6.43 & 16.55 & 21.67 & 69.28 & 12.02 \\
\hline \multirow[t]{3}{*}{ Coucal } & W 1 & 4,825 & 46.50 & 57.05 & 6.90 & 17.71 & 16.82 & 106.82 & 13.74 \\
\hline & W 2 & 4,022 & 51.17 & 80.77 & 6.07 & 24.97 & 17.82 & 90.71 & 12.84 \\
\hline & W 3 & 2,784 & 50.99 & 48.41 & 5.57 & 18.91 & 17.75 & 60.03 & 11.76 \\
\hline \multirow[t]{3}{*}{ Loerie II } & W 1 & 5,428 & 47.08 & 59.32 & 7.40 & 25.68 & 33.7 & 80.09 & 13.45 \\
\hline & W 2 & 4,650 & 53.33 & 62.61 & 6.61 & 22.13 & 26.53 & 73.03 & 12.43 \\
\hline & W 3 & 4,408 & 48.08 & 42.98 & 6.19 & 15.72 & 23.24 & 70.02 & 10.89 \\
\hline \multirow[t]{3}{*}{ Mampolyo } & W 1 & 6,466 & 50.12 & 64.76 & 7.55 & 27.06 & 31.18 & 82.67 & 14.94 \\
\hline & W 2 & 4,932 & 42.68 & 69.20 & 6.36 & 26.46 & 27.86 & 74.32 & 12.40 \\
\hline & W 3 & 3,793 & 52.70 & 69.99 & 6.85 & 24.50 & 26.5 & 67.85 & 12.44 \\
\hline \multirow[t]{3}{*}{ Nduna } & W 1 & 6,253 & 46.04 & 52.42 & 7.10 & 24.19 & 31.72 & 78.29 & 12.28 \\
\hline & W 2 & 4,490 & 46.89 & 54.00 & 6.27 & 19.27 & 23.13 & 70.68 & 12.16 \\
\hline & W 3 & 3,340 & 40.14 & 30.09 & 5.67 & 14.75 & 19.92 & 57.50 & 11.36 \\
\hline \multirow[t]{3}{*}{ NBA } & W 1 & 5,179 & 44.42 & 69.05 & 7.07 & 25.60 & 25.57 & 81.82 & 12.63 \\
\hline & W 2 & 4,667 & 42.72 & 60.37 & 6.37 & 21.07 & 27.02 & 74.53 & 11.19 \\
\hline & W 3 & 3,705 & 53.39 & 39.66 & 6.25 & 15.16 & 20.58 & 67.55 & 11.03 \\
\hline \multirow[t]{3}{*}{ Pungwe } & W 1 & 5,943 & 42.57 & 54.54 & 7.16 & 21.04 & 25.33 & 83.05 & 13.72 \\
\hline & W 2 & 4,807 & 42.24 & 51.52 & 6.34 & 20.18 & 26.67 & 75.42 & 11.68 \\
\hline & W 3 & 3,553 & 45.87 & 42.31 & 6.55 & 13.86 & 21.24 & 65.33 & 11.15 \\
\hline \multirow[t]{3}{*}{ Sahai I } & W 1 & 5,873 & 47.23 & 70.87 & 7.41 & 22.47 & 25.21 & 89.14 & 13.64 \\
\hline & W 2 & 4,553 & 51.92 & 67.34 & 6.70 & 23.10 & 24.24 & 79.41 & 11.71 \\
\hline & W 3 & 4,511 & 52.52 & 46.65 & 6.12 & 16.88 & 24.77 & 62.94 & 10.70 \\
\hline \multirow[t]{3}{*}{ Secure } & W 1 & 4,746 & 49.37 & 60.92 & 7.91 & 17.56 & 20.44 & 81.62 & 14.16 \\
\hline & W 2 & 4,522 & 49.86 & 62.07 & 7.41 & 16.23 & 24.31 & 70.79 & 12.96 \\
\hline & W 3 & 3,492 & 51.24 & 59.69 & 6.80 & 16.53 & 21.41 & 66.50 & 12.24 \\
\hline \multirow[t]{3}{*}{ Shine } & W 1 & 5,202 & 43.89 & 61.00 & 6.77 & 20.67 & 25.08 & 80.37 & 12.19 \\
\hline & W 2 & 4,568 & 54.44 & 65.44 & 5.80 & 24.71 & 24.99 & 70.33 & 10.87 \\
\hline & W 3 & 3,022 & 51.58 & 51.20 & 6.18 & 13.13 & 19.24 & 63.21 & 11.46 \\
\hline \multirow[t]{3}{*}{ UNZA I } & W 1 & 5,174 & 43.26 & 47.99 & 6.62 & 20.68 & 29.25 & 76.36 & 11.09 \\
\hline & W 2 & 3,908 & 46.75 & 43.99 & 5.98 & 15.21 & 22.76 & 69.62 & 9.86 \\
\hline & W 3 & 3,060 & 47.04 & 32.37 & 6.25 & 10.99 & 17.25 & 62.75 & 9.66 \\
\hline \multirow[t]{3}{*}{ UNZA II } & W 1 & 4,802 & 49.96 & 51.72 & 6.74 & 14.03 & 23.48 & 74.78 & 11.68 \\
\hline & W 2 & 4,286 & 44.87 & 66.81 & 6.24 & 22.86 & 24.24 & 74.70 & 11.87 \\
\hline & W 3 & 3,235 & 46.21 & 55.57 & 6.06 & 11.92 & 19.1 & 62.25 & 10.85 \\
\hline $\operatorname{LSD}(5 \%)$ & & 616.4 & 3.22 & 6.56 & 0.79 & 3.68 & 2.66 & 4.35 & 1.84 \\
\hline \multirow{2}{*}{\multicolumn{10}{|c|}{$\begin{array}{cc}\text { BM: } & \text { Above ground biomass, G.E.: Grai } \\
\text { S.E.: } & \text { Spikes per ear, E.L.: Ear length }\end{array}$}} \\
\hline & & & W 1 : & $0 \%, \mathrm{~W} 2$ & $5 \%, W$ & $50 \%$ & & & \\
\hline
\end{tabular}


Table 5 : Effect of Nitrogen Rates and Genotype Interaction on Grain Yield and Yield Components

\begin{tabular}{|c|c|c|c|c|c|c|c|c|c|}
\hline Genotype & Nitrogen & Yield & TKW & BM & EL & GE & HI & PHT & SE \\
\hline \multirow{3}{*}{ Choza } & N 1 & 4,049 & 50.21 & 59.13 & 6.76 & 19.30 & 20.00 & 73.00 & 12.64 \\
\hline & $\mathrm{N} 2$ & 4,135 & 51.50 & 42.84 & 6.99 & 19.00 & 27.63 & 78.03 & 12.83 \\
\hline & N 3 & 4,499 & 50.53 & 56.14 & 6.33 & 21.07 & 24.27 & 77.02 & 12.06 \\
\hline \multirow{3}{*}{ Coucal } & N 1 & 4,804 & 50.79 & 66.84 & 6.16 & 25.32 & 17.07 & 85.31 & 12.97 \\
\hline & N 2 & 3,656 & 49.08 & 52.74 & 6.02 & 20.23 & 18.16 & 86.82 & 12.02 \\
\hline & N 3 & 3,171 & 48.79 & 66.65 & 6.37 & 16.04 & 17.16 & 85.41 & 13.35 \\
\hline \multirow{3}{*}{ Loerie II } & $\mathrm{N} 1$ & 5,229 & 48.35 & 62.73 & 7.03 & 22.92 & 28.20 & 77.89 & 12.86 \\
\hline & N 2 & 5,276 & 52.86 & 58.00 & 6.44 & 22.64 & 29.55 & 74.32 & 11.55 \\
\hline & N 3 & 3,980 & 47.28 & 44.18 & 6.73 & 17.96 & 25.72 & 70.93 & 12.36 \\
\hline \multirow{3}{*}{ Mampolyo } & N 1 & 5,838 & 55.35 & 64.06 & 7.00 & 24.12 & 32.50 & 74.27 & 13.46 \\
\hline & $\mathrm{N} 2$ & 4,895 & 45.65 & 74.19 & 6.77 & 25.87 & 26.08 & 74.43 & 13.03 \\
\hline & N 3 & 4,458 & 44.51 & 65.70 & 6.99 & 28.03 & 26.95 & 76.14 & 13.31 \\
\hline \multirow{3}{*}{ Nduna } & $\mathrm{N} 1$ & 4,155 & 40.71 & 43.93 & 6.80 & 21.08 & 24.64 & 72.50 & 11.52 \\
\hline & $\mathrm{N} 2$ & 5,072 & 51.91 & 52.18 & 6.25 & 21.25 & 27.66 & 68.71 & 12.45 \\
\hline & N 3 & 4,856 & 40.45 & 40.41 & 6.00 & 15.87 & 22.48 & 65.26 & 11.83 \\
\hline \multirow{3}{*}{ NBA } & $\mathrm{N} 1$ & 4,643 & 49.48 & 65.18 & 6.63 & 22.45 & 25.83 & 74.13 & 12.25 \\
\hline & $\mathrm{N} 2$ & 4,536 & 43.92 & 45.57 & 6.80 & 19.68 & 26.36 & 73.47 & 11.36 \\
\hline & $\mathrm{N} 3$ & 4,373 & 47.14 & 58.32 & 6.27 & 19.70 & 20.98 & 76.29 & 11.24 \\
\hline \multirow{3}{*}{ Pungwe } & N 1 & 4,918 & 42.24 & 46.69 & 6.55 & 19.48 & 26.41 & 75.38 & 11.84 \\
\hline & $\mathrm{N} 2$ & 4,832 & 43.14 & 53.08 & 6.91 & 18.29 & 23.88 & 77.86 & 13.75 \\
\hline & N 3 & 4,554 & 45.29 & 48.59 & 6.58 & 17.31 & 22.95 & 70.55 & 10.95 \\
\hline \multirow{3}{*}{ Sahai I } & N 1 & 5,669 & 52.45 & 68.81 & 7.22 & 22.42 & 26.17 & 81.53 & 13.10 \\
\hline & N 2 & 4,709 & 49.36 & 62.47 & 6.80 & 21.46 & 25.04 & 74.17 & 11.86 \\
\hline & N 3 & 4,558 & 49.86 & 53.58 & 6.21 & 18.57 & 23.01 & 75.78 & 11.09 \\
\hline \multirow{3}{*}{ Secure } & N 1 & 4,924 & 50.50 & 69.68 & 7.63 & 22.75 & 23.11 & 75.50 & 13.33 \\
\hline & $\mathrm{N} 2$ & 4,471 & 55.03 & 63.02 & 7.15 & 13.04 & 19.74 & 69.98 & 12.63 \\
\hline & N 3 & 3,364 & 44.94 & 49.98 & 7.34 & 14.53 & 23.31 & 73.44 & 13.41 \\
\hline \multirow{3}{*}{ Shine } & $\mathrm{N} 1$ & 4,751 & 51.46 & 59.92 & 5.90 & 20.34 & 24.53 & 69.27 & 11.57 \\
\hline & $\mathrm{N} 2$ & 3,942 & 49.09 & 48.32 & 6.14 & 16.22 & 22.25 & 70.64 & 11.37 \\
\hline & N 3 & 4,099 & 49.35 & 69.40 & 6.71 & 21.95 & 22.53 & 73.99 & 11.58 \\
\hline \multirow[t]{3}{*}{ UNZA I } & N 1 & 4,212 & 44.14 & 40.92 & 6.77 & 17.08 & 26.78 & 68.31 & 10.61 \\
\hline & $\mathrm{N} 2$ & 4,011 & 51.15 & 39.47 & 5.82 & 15.64 & 21.12 & 69.06 & 10.26 \\
\hline & N 3 & 3,919 & 41.76 & 43.97 & 6.26 & 14.16 & 21.35 & 71.34 & 9.75 \\
\hline \multirow[t]{3}{*}{ UNZA II } & N 1 & 4,794 & 48.64 & 49.14 & 6.81 & 13.90 & 21.92 & 67.31 & 11.67 \\
\hline & $\mathrm{N} 2$ & 4,320 & 48.01 & 60.39 & 6.23 & 16.23 & 24.99 & 73.74 & 12.17 \\
\hline & N 3 & 3,209 & 44.38 & 64.57 & 5.99 & 18.67 & 19.91 & 70.67 & 10.56 \\
\hline LSD (5\%) & & 358 & 2.53 & 5.26 & 0.44 & 2.54 & 2.30 & 2.82 & 1.00 \\
\hline \multicolumn{10}{|c|}{ BM: Above ground biomass, G.E.: Grains per ear, PHT : Plant height, HI : Harvest index } \\
\hline & C.: Spikes pe & ear, E.L. & ar length & N $1: 24$ & $\mathrm{sha}^{-1}, \mathrm{l}$ & $: 160 \mathrm{~kg}$ & $-1, \mathbf{N} 3:$ & $\operatorname{sgha}^{-1}$ & \\
\hline
\end{tabular}




\section{Table 6 : Effect of Water and Nitrogen and Genotype Interaction on Grain Yield} and Yield Components

\begin{tabular}{|c|c|c|c|c|c|c|c|c|c|c|}
\hline Genotype & Water & Nitrogen & Yield & TKW & BM & EL & GE & HI & PHT & SE \\
\hline \multirow[t]{9}{*}{ Choza } & W 1 & N 1 & 5,203 & 58.49 & 78.39 & 7.02 & 21.31 & 23.94 & 79.48 & 13.86 \\
\hline & & $\mathrm{N} 2$ & 4,808 & 48.87 & 55.54 & 7.30 & 24.82 & 27.02 & 87.56 & 13.81 \\
\hline & & N 3 & 4,433 & 43.22 & 62.94 & 6.98 & 21.42 & 21.48 & 86.75 & 12.75 \\
\hline & W 2 & $\mathrm{~N} 1$ & 3,959 & 42.76 & 51.77 & 6.63 & 20.19 & 21.16 & 70.27 & 12.06 \\
\hline & & N 2 & 3,603 & 41.93 & 46.61 & 6.84 & 19.38 & 28.49 & 74.87 & 12.25 \\
\hline & & N 3 & 5,559 & 49.04 & 51.33 & 6.16 & 21.37 & 28.59 & 77.35 & 11.79 \\
\hline & W 3 & N 1 & 2,985 & 49.39 & 47.24 & 6.62 & 16.40 & 14.91 & 69.24 & 12.00 \\
\hline & & $\mathrm{N} 2$ & 3,995 & 63.71 & 26.36 & 6.81 & 12.82 & 27.38 & 71.64 & 12.43 \\
\hline & & N 3 & 3,505 & 59.33 & 54.14 & 5.86 & 20.43 & 22.73 & 66.96 & 11.64 \\
\hline \multirow[t]{9}{*}{ Coucal } & W 1 & $\mathrm{~N} 1$ & 5,300 & 41.75 & 50.36 & 7.06 & 21.74 & 20.30 & 98.46 & 13.31 \\
\hline & & $\mathrm{N} 2$ & 4,819 & 48.14 & 52.43 & 6.28 & 18.66 & 18.97 & 112.08 & 13.03 \\
\hline & & N 3 & 4,358 & 49.60 & 68.35 & 7.36 & 12.73 & 11.19 & 109.91 & 14.88 \\
\hline & W 2 & $\mathrm{~N} 1$ & 5,435 & 64.16 & 102.06 & 5.80 & 33.05 & 18.21 & 85.12 & 13.79 \\
\hline & & $\mathrm{N} 2$ & 3,659 & 48.52 & 55.30 & 5.85 & 20.45 & 16.85 & 94.15 & 11.47 \\
\hline & & N 3 & 2,973 & 40.83 & 84.94 & 6.58 & 21.43 & 18.41 & 92.85 & 13.25 \\
\hline & W 3 & $\mathrm{~N} 1$ & 3,678 & 46.45 & 48.10 & 5.61 & 21.18 & 12.72 & 72.35 & 11.82 \\
\hline & & $\mathrm{N} 2$ & 2,492 & 50.59 & 50.48 & 5.95 & 21.60 & 18.66 & 54.24 & 11.55 \\
\hline & & N 3 & 2,181 & 55.93 & 46.66 & 5.16 & 13.95 & 21.88 & 53.48 & 11.92 \\
\hline \multirow[t]{9}{*}{ Loerie II } & W 1 & $\mathrm{~N} 1$ & 4,936 & 43.61 & 66.30 & 7.67 & 27.93 & 34.22 & 80.85 & 13.75 \\
\hline & & $\mathrm{N} 2$ & 6,805 & 57.52 & 65.40 & 7.58 & 28.95 & 35.05 & 80.76 & 13.86 \\
\hline & & N 3 & 4,541 & 40.12 & 46.26 & 6.95 & 20.17 & 31.84 & 78.65 & 12.75 \\
\hline & W 2 & $\mathrm{~N} 1$ & 5,399 & 51.96 & 69.96 & 6.59 & 21.44 & 24.15 & 79.06 & 13.36 \\
\hline & & N 2 & 4,741 & 54.74 & 59.15 & 5.99 & 22.66 & 30.41 & 68.95 & 10.92 \\
\hline & & N 3 & 3,809 & 53.29 & 58.71 & 7.25 & 22.28 & 25.02 & 71.06 & 13.00 \\
\hline & W 3 & N 1 & 5,351 & 49.48 & 51.92 & 6.82 & 19.39 & 26.23 & 73.75 & 11.46 \\
\hline & & N 2 & 4,282 & 46.33 & 49.45 & 5.77 & 16.32 & 23.20 & 73.23 & 9.88 \\
\hline & & N 3 & 3,591 & 48.42 & 27.57 & 5.99 & 11.44 & 20.29 & 63.09 & 11.33 \\
\hline \multirow[t]{9}{*}{ Mampolyo } & W 1 & $\mathrm{~N} 1$ & 7,346 & 59.89 & 47.61 & 7.37 & 22.66 & 34.68 & 80.56 & 14.75 \\
\hline & & $\mathrm{N} 2$ & 5,578 & 47.43 & 65.25 & 7.29 & 30.77 & 30.39 & 82.72 & 14.33 \\
\hline & & N 3 & 6,473 & 43.05 & 81.44 & 8.00 & 27.76 & 28.46 & 84.73 & 15.75 \\
\hline & W 2 & N 1 & 5,212 & 48.22 & 71.32 & 6.05 & 22.69 & 29.96 & 68.90 & 11.71 \\
\hline & & $\mathrm{N} 2$ & 5,703 & 39.11 & 73.61 & 6.80 & 26.42 & 25.81 & 77.90 & 13.61 \\
\hline & & N 3 & 3,881 & 40.72 & 62.67 & 6.22 & 30.27 & 27.80 & 76.18 & 11.89 \\
\hline & W 3 & $\mathrm{~N} 1$ & 4,957 & 57.93 & 73.27 & 7.56 & 27.02 & 32.87 & 73.35 & 13.92 \\
\hline & & $\mathrm{N} 2$ & 3,405 & 50.43 & 83.70 & 6.22 & 20.42 & 22.03 & 62.68 & 11.14 \\
\hline & & N 3 & 3,018 & 49.74 & 52.99 & 6.77 & 26.08 & 24.60 & 67.51 & 12.28 \\
\hline \multirow[t]{7}{*}{ Nduna } & W 1 & N 1 & 5,453 & 43.47 & 49.91 & 8.00 & 27.96 & 34.91 & 81.06 & 11.29 \\
\hline & & $\mathrm{N} 2$ & 6,811 & 50.79 & 61.62 & 6.64 & 27.02 & 30.38 & 78.82 & 13.47 \\
\hline & & N 3 & 6,494 & 43.86 & 45.75 & 6.66 & 17.58 & 29.88 & 74.99 & 12.08 \\
\hline & W 2 & $\mathrm{~N} 1$ & 4,038 & 40.52 & 42.47 & 5.84 & 16.33 & 23.22 & 69.94 & 11.42 \\
\hline & & N 2 & 4,949 & 59.56 & 71.82 & 6.27 & 21.05 & 20.99 & 72.25 & 12.55 \\
\hline & & N 3 & 4,483 & 40.59 & 47.71 & 6.71 & 20.44 & 25.18 & 69.86 & 12.53 \\
\hline & W 3 & N 1 & 2,973 & 38.15 & 39.40 & 6.55 & 18.95 & 15.78 & 66.50 & 11.86 \\
\hline
\end{tabular}




\begin{tabular}{|c|c|c|c|c|c|c|c|c|c|c|}
\hline & & N 2 & 3,456 & 45.37 & 23.11 & 5.84 & 15.69 & 31.60 & 55.06 & 11.33 \\
\hline & & N 3 & 3,590 & 36.89 & 27.77 & 4.62 & 9.60 & 12.37 & 50.94 & 10.89 \\
\hline \multirow[t]{9}{*}{ NBA } & W 1 & N 1 & 5,608 & 45.23 & 87.77 & 7.27 & 28.82 & 26.00 & 82.73 & 13.22 \\
\hline & & N 2 & 5,680 & 44.79 & 52.02 & 7.49 & 19.24 & 27.16 & 81.82 & 12.89 \\
\hline & & N 3 & 4,247 & 43.25 & 67.37 & 6.46 & 28.74 & 23.56 & 80.90 & 11.79 \\
\hline & W 2 & N 1 & 4,234 & 44.27 & 56.02 & 6.01 & 20.01 & 27.65 & 73.46 & 11.01 \\
\hline & & $\mathrm{N} 2$ & 4,101 & 39.08 & 61.75 & 6.88 & 22.74 & 28.60 & 70.82 & 11.17 \\
\hline & & N 3 & 5,667 & 44.82 & 63.34 & 6.23 & 20.47 & 24.81 & 79.32 & 11.38 \\
\hline & W 3 & $\mathrm{~N} 1$ & 4,087 & 58.94 & 51.76 & 6.60 & 18.52 & 23.85 & 66.21 & 12.53 \\
\hline & & N 2 & 3,825 & 47.88 & 22.95 & 6.03 & 17.08 & 23.31 & 67.78 & 10.01 \\
\hline & & N 3 & 3,204 & 53.34 & 44.26 & 6.14 & 9.88 & 14.57 & 68.67 & 10.54 \\
\hline \multirow[t]{9}{*}{ Pungwe } & W 1 & $\mathrm{~N} 1$ & 5,679 & 37.80 & 39.79 & 6.61 & 18.75 & 23.46 & 79.14 & 13.03 \\
\hline & & N 2 & 5,755 & 42.90 & 71.85 & 8.02 & 24.67 & 24.74 & 87.32 & 17.25 \\
\hline & & N 3 & 6,395 & 47.01 & 51.97 & 6.85 & 19.72 & 27.79 & 82.70 & 10.88 \\
\hline & W 2 & N 1 & 5,109 & 43.39 & 53.04 & 6.30 & 23.07 & 30.22 & 76.37 & 11.42 \\
\hline & & N 2 & 4,320 & 41.68 & 50.42 & 6.53 & 15.57 & 21.11 & 74.75 & 11.95 \\
\hline & & N 3 & 4,993 & 41.65 & 51.09 & 6.20 & 21.91 & 28.67 & 75.12 & 11.67 \\
\hline & W 3 & $\mathrm{~N} 1$ & 3,965 & 45.54 & 47.23 & 6.75 & 16.63 & 25.54 & 70.64 & 11.08 \\
\hline & & $\mathrm{N} 2$ & 4,420 & 44.86 & 36.99 & 6.20 & 14.62 & 25.79 & 71.51 & 12.06 \\
\hline & & N 3 & 2,273 & 47.21 & 42.72 & 6.71 & 10.32 & 12.39 & 53.83 & 10.31 \\
\hline \multirow[t]{9}{*}{ Sahai I } & W 1 & N 1 & 6,195 & 45.12 & 67.64 & 7.47 & 21.22 & 27.54 & 90.72 & 14.25 \\
\hline & & $\mathrm{N} 2$ & 6,061 & 47.49 & 87.82 & 7.74 & 25.38 & 24.46 & 85.38 & 14.00 \\
\hline & & N 3 & 5,363 & 49.08 & 57.15 & 7.02 & 20.81 & 23.63 & 91.31 & 12.67 \\
\hline & W 2 & N 1 & 4,726 & 50.83 & 81.94 & 7.32 & 27.72 & 23.70 & 82.56 & 13.11 \\
\hline & & $\mathrm{N} 2$ & 4,175 & 52.23 & 58.62 & 6.13 & 22.25 & 24.07 & 73.10 & 11.08 \\
\hline & & N 3 & 4,757 & 52.69 & 61.47 & 6.64 & 19.34 & 24.95 & 82.56 & 10.94 \\
\hline & W 3 & $\mathrm{~N} 1$ & 6,086 & 61.40 & 56.85 & 6.85 & 18.30 & 27.27 & 71.31 & 11.94 \\
\hline & & $\mathrm{N} 2$ & 3,891 & 48.35 & 40.99 & 6.52 & 16.76 & 26.61 & 64.04 & 10.50 \\
\hline & & N 3 & 3,555 & 47.81 & 42.10 & 4.97 & 15.56 & 20.44 & 53.46 & 9.67 \\
\hline \multirow[t]{9}{*}{ Secure } & W 1 & N 1 & 4,996 & 47.01 & 68.66 & 8.02 & 21.47 & 20.24 & 84.44 & 14.83 \\
\hline & & $\mathrm{N} 2$ & 5,148 & 58.86 & 55.57 & 7.07 & 11.80 & 17.89 & 80.25 & 11.96 \\
\hline & & N 3 & 4,094 & 42.26 & 58.51 & 8.65 & 19.40 & 23.19 & 80.19 & 15.69 \\
\hline & W 2 & $\mathrm{~N} 1$ & 5,212 & 53.37 & 63.77 & 7.66 & 20.00 & 26.50 & 69.04 & 13.18 \\
\hline & & $\mathrm{N} 2$ & 5,328 & 53.04 & 79.56 & 7.47 & 14.68 & 20.28 & 69.44 & 13.25 \\
\hline & & N 3 & 3,025 & 43.17 & 42.88 & 7.09 & 14.02 & 26.14 & 73.90 & 12.46 \\
\hline & W 3 & $\mathrm{~N} 1$ & 4,565 & 51.13 & 76.61 & 7.20 & 26.77 & 22.59 & 73.02 & 11.98 \\
\hline & & $\mathrm{N} 2$ & 2,937 & 53.18 & 53.92 & 6.91 & 12.63 & 21.07 & 60.25 & 12.67 \\
\hline & & N 3 & 2,974 & 49.41 & 48.54 & 6.30 & 10.18 & 20.59 & 66.24 & 12.08 \\
\hline \multirow[t]{8}{*}{ Shine } & W 1 & N 1 & 5,658 & 43.16 & 56.11 & 6.05 & 22.34 & 28.80 & 76.01 & 11.88 \\
\hline & & N 2 & 5,802 & 43.06 & 53.15 & 7.22 & 15.94 & 21.73 & 79.44 & 12.71 \\
\hline & & N 3 & 4,148 & 45.45 & 73.73 & 7.03 & 23.73 & 24.70 & 85.65 & 11.97 \\
\hline & W 2 & $\mathrm{~N} 1$ & 4,795 & 55.21 & 60.15 & 5.66 & 23.71 & 28.30 & 67.05 & 11.51 \\
\hline & & $\mathrm{N} 2$ & 3,684 & 49.55 & 55.65 & 4.89 & 20.82 & 22.34 & 70.21 & 9.63 \\
\hline & & N 3 & 5,224 & 58.55 & 80.53 & 6.85 & 29.60 & 24.34 & 73.73 & 11.48 \\
\hline & W 3 & N 1 & 3,801 & 56.01 & 63.52 & 5.98 & 14.96 & 16.50 & 64.76 & 11.32 \\
\hline & & N 2 & 2,340 & 54.67 & 36.17 & 6.31 & 11.91 & 22.67 & 62.27 & 11.78 \\
\hline
\end{tabular}




\begin{tabular}{|c|c|c|c|c|c|c|c|c|c|c|}
\hline & & N 3 & 2,925 & 44.06 & 53.93 & 6.25 & 12.52 & 18.53 & 62.58 & 11.28 \\
\hline \multirow[t]{9}{*}{ UNZA I } & W 1 & N 1 & 5,629 & 44.55 & 45.22 & 6.89 & 24.03 & 41.58 & 76.15 & 10.58 \\
\hline & & N 2 & 5,246 & 47.62 & 43.24 & 6.50 & 15.59 & 22.59 & 71.86 & 12.13 \\
\hline & & N 3 & 4,646 & 37.61 & 55.51 & 6.46 & 22.41 & 23.58 & 81.06 & 10.55 \\
\hline & W 2 & $\mathrm{~N} 1$ & 3,801 & 45.36 & 42.11 & 5.79 & 11.84 & 22.50 & 64.94 & 9.40 \\
\hline & & N 2 & 3,442 & 52.08 & 44.28 & 5.54 & 20.96 & 22.06 & 72.46 & 9.57 \\
\hline & & N 3 & 4,481 & 42.81 & 45.57 & 6.61 & 12.81 & 23.71 & 71.46 & 10.63 \\
\hline & W 3 & N 1 & 3,205 & 42.50 & 35.42 & 7.65 & 15.36 & 16.25 & 63.86 & 11.84 \\
\hline & & $\mathrm{N} 2$ & 3,344 & 53.75 & 30.89 & 5.41 & 10.36 & 18.72 & 62.87 & 9.08 \\
\hline & & N 3 & 2,630 & 44.87 & 30.81 & 5.69 & 7.26 & 16.76 & 61.51 & 8.07 \\
\hline \multirow[t]{9}{*}{ UNZA II } & W 1 & $\mathrm{~N} 1$ & 5,212 & 56.14 & 61.08 & 8.02 & 11.95 & 23.63 & 68.15 & 11.90 \\
\hline & & $\mathrm{N} 2$ & 5,625 & 49.07 & 49.33 & 6.46 & 16.65 & 25.56 & 81.67 & 13.60 \\
\hline & & N 3 & 3,568 & 44.67 & 44.75 & 5.73 & 13.49 & 21.25 & 74.53 & 9.54 \\
\hline & W 2 & N 1 & 4,644 & 44.86 & 44.60 & 5.98 & 17.63 & 23.56 & 74.77 & 11.89 \\
\hline & & $\mathrm{N} 2$ & 4,350 & 43.43 & 66.10 & 5.84 & 21.09 & 21.47 & 72.58 & 11.75 \\
\hline & & N 3 & 3,863 & 46.31 & 89.74 & 6.91 & 29.85 & 27.68 & 76.75 & 11.97 \\
\hline & W 3 & N 1 & 4,525 & 44.93 & 41.75 & 6.45 & 12.12 & 18.58 & 59.01 & 11.24 \\
\hline & & $\mathrm{N} 2$ & 2,984 & 51.54 & 65.73 & 6.40 & 10.95 & 27.94 & 66.98 & 11.15 \\
\hline & & N 3 & 2,198 & 42.17 & 59.21 & 5.32 & 12.69 & 10.78 & 60.75 & 10.17 \\
\hline LSD (5\%) & & & 765 & 4.76 & 9.81 & 0.95 & 5.02 & 4.17 & 5.70 & 2.21 \\
\hline
\end{tabular}

BM: Above ground biomass, G.E.: Grains per ear, PHT : Plant height, HI : Harvest index, S.E.: Spikes per ear,

EL: $\quad$ Ear length, W 1: 100\%, W 2: 75\%, W $3: 50 \%, \mathrm{~N}^{1}: 240 \mathrm{kgha}^{-1}, \mathrm{~N} 2: 160 \mathrm{kgha}^{-1}$ and N $3: 80 \mathrm{kgha}^{-1}$ 